We cannot directly relate the findings in this study to the developrient of clinical arterial disease, for its prevalence was low and the group was small. The provocative relations which have emerged, however, justify a speculative attempt to link the biochemical changes in the normal population sample with a disease which is so common in our society.

This work was supported by a research grant from the Ministry of Health and also owes much to the generous and friendly cooperation of the staff of Beecham Laboratories. Assays and estimations were aided by apparatus provided by the Wellcome Foundation. We would also like to thank the staff of the Computer Centre, University College, London, for their help in the computer analysis and we are grateful for the support and advice provided by Professor W. J. H. Butterfield, Professor I. Macdonald, and Dr. M. Brook.

ADDENDUM: Since these papers were accepted for publication we have learned of the work of Timms et al. (1968). These authors showed that the estimation of triglycerides in rat serum by Lofland's semi-automated method gave consistently higher values than two other methods. They suggest that this discrepancy is due to "contamination of the isopropanol extracts by glucose or other carbohydrates." However, we consider it highly unlikely that this phenomenon plays any part in the relationships discussed in our papers for the following reasons: (1) only a very small proportion of the variation in fasting glyceride levels could be accounted for by variation in the accompanying levels of fasting blood sugar, (2) the mean fasting glyceride level is significantly different in the two sexes (men 93.4 , women $81.9 ; 0.01>P>0.001$ ), whereas the mean fasting blood sugar levels are almost identical (men 83.06, women 81.22$)$; (3) although the fasting blood sugar is highly correlated with the fasting glycerides in the men $(r=0.36)$, it is not in the women $(r=0.07)$; and (4) despite a clear correlation between age and fasting glycerides in both sexes (men, $r=0.42$; women, $r=0 \cdot 21$ ), the correlation between age and fasting blood sugar is not significant in women $(r=0.07)$ and significant only at the $5 \%$ level in men $(r=0 \cdot 24)$.
REFERENCES

Ahrens, E. H., jun., Hirsch, J., Oette, K., Farquhar, J. W., and Stein, Y. (1961). Trans. Ass. Amer. Phycns 74, 134.

Albrink, M. J., and Meigs, J. W. (1964). Amer. F. clin. Nutr., 15, 255.

Bowen, A. J., and Reeves, R. L. (1967). Arch. intern. Med., 119, 261.

Boyns, D. R., Crossley, J. N,, Abrams, M. E., Jarrett, R. J., and Keen, H. (1969). Brit. med. F., 1, 595.

Butterfield, W. J. H. (1964). Proc. roy. Soc. Med., 57, 196.

Chlouverakis, C., Jarrett, R. J., and Keen, H. (1967). Lancet, 1, 806.

Dixon, W. J. (editor) (1965). Biomedical Computer Programs. University of California, Los Angeles.

Epstein, F. H. (1967). F. Amer. med. Ass., 201, 795.

Farquhar, J. W., Frank, A., Gross, R. C., and Reaven, G. M. (1966). 7. clin. Invest., 45, 1648 .

Gordon, T. (1964). Vital and Health Statistics, series 11, No. 2. Washington.

Harlan, W. R., jun., Oberman, A., Mitchell, R. E., and Graybiel, A. (1967). Ann. intern. Med., 66, 540.

Havel, R. J. (1957). F. clin. Invest., 36, 855.

Himsworth, H. P. (1935). Clin. Sci., 2, 67.

Jarrett, R. J., and Graver, H. J. (1968). Brit. med. 7., 2, 528.

Jarrett, R. J., and Keen, H. (1968). Communication to the Medical and Scientific Section of the British Diabetic Association, Aberdeen, 27-28 September.

Keen, H. (1964). Proc. roy. Soc. Med., 57, 200.

Keen, H., and Rose, G. A. (1958). Brit. med. F., 1, 1508

Keen, H., Rose, G., Pyke, D. A., Boyns, D., Chlouverakis, C., and Mistry, S. (1965). Lancet, 2, 505.

Kessler, J. I. (1962). F. Lab. clin. Med., 60, 747.

Macdonald, I. (1967). Amer. F. clin. Nutr., 20, 345

Mahler, R., Stafford, W. S., Tarrant, M. E., and Ashmore, J. (1964). Diabetes, 13, 297.

Oliver, M. F., and Boyd, G. S. (1959). Lancet, 2, 690

Ostrander, L. D., jun., Francis, T., jun., Hayner, N. S., Kjelsberg, M. O. and Epstein F. H. (1965). Ann. intern Med., 62, 1188.

Ostrander, L. D., jun., Neff, B. J., Block, W. D., Francis, T., jun., and Epstein, F. H. (1967). Ann. intern. Med., 67, 34.

O'Sullivan, J. B. (1961). New Engl. F. Med., 264, 1082.

Perley, M. J., and Kipnis, D. M. (1967). F. clin. Invest., 46, 1954.

Reaven, G. M., Lerner, R. L., Stern, M. P., and Farquhar, J. W. (1967). f. clin. Invest., 46, 1756.

Sailer, S., Sandhofer, F., and Braunsteiner, H. (1966). Metabolism, 15,

Salans, L. B., and Reaven, G. M. (1966). Proc. Soc. exp. Biol. (N.Y.), 122,1208 .

Schlierf, G., and Kinsell, L. W. (1965). Proc. Soc. exp. Biol. (N.Y.), $120,272$.

Sharp, C. L. (1964). Proc. roy. Soc. Med., 57, 193.

Timms, A. R., Kelly, L. A., Spirito, J. A., and Engstrom, R. G. (1968). 7. Lipid Res., 9, 675.

Wilkerson, H. L. C., Butler, F. K., and Francis, J. O'S. (1960). Diabetes, 9, 386 .

Many authors have commented on alterations in liver function in women taking oral contraceptives (Ockner and Davidson, 1967). Some have attempted to elucidate whether such changes

* Hodge Research Scholar.

† Senior Lecturer, Department of Obstetrics and Gynaecology.

Welsh National School of Medicine, Cardiff.

are due to the oestrogen or the progestogen in any combination tablet (Adlercreutz and Ikonen, 1964 ; Eisalo et al., 1964, 1968). This is not an easy task, because most of the progestogens used are $17 \alpha$-alkynyl substituted derivatives of nortestosterone which may to a small extent be metabolized to oestrogens (Brown and Blair, 1960 ; Paulsen et al., 1962). Further difficulty arises because the conventional liver function tests are relatively insensitive and may not be significantly altered by the functional changes induced by these drugs. In this work an attempt has been made to determine the more subtle changes by using the modified bromsulphthalein (B.S.P.) test described by Richards et al. (1959). A group of conventional liver function tests have also been performed on each patient. For reasons mentioned above only two drugs have been studied: a pure synthetic oestrogen, stilboestrol, and a pure progestogen, megestrol acetate. By making use of the puerperium it has been possible to administer much larger doses of these than are normally used for gynaecological or contraceptive purposes and to accentuate any stress they may place on the liver. Megestrol acetate is 6 -methyl, $17 \alpha$-acetoxy progesterone, and, unlike the nortestosterone derivatives, is not metabolized to oestrogenic compounds. At present it is used in three oral contraceptives. 


\section{Methods and Materials}

Liver Function Tests.-The conventional tests performed (with their upper limits or normal for the early puerperium given in parentheses) were: serum bilirubin $(0.8 \mathrm{mg} . / 100 \mathrm{ml}$.), alkaline phosphatase (18 King-Armstrong units), thymol turbidity (4 units), serum alanine aminotransferase (35 Rosalki units), and the 45-minute B.S.P. retention level (5\%). The steps involved in performing the modified B.S.P. test have been described in detail by Tindall and Beazley (1965) in pregnant women. The test was performed under basal conditions in the fasting state. A standard dose of B.S.P. (300 mg.) was injected intravenously, following which 10 to 12 blood samples were taken at different times over a period of 75 minutes. The concentration of B.S.P. present in the plasma was determined in a similar manner to that described by Barber-Riley et al. (1961). The information derived from knowledge of the pattern of B.S.P. disappearance is considered in the results.

Patients Tested.-(1) Twenty normal puerperal women who were breast-feeding to act as a control group, (2) 24 normal puerperal women who had lactation suppressed with stilboestrol, and (3) 21 normal puerperal women who had lactation suppressed with megestrol acetate. All women tested had had a spontaneous vaginal or a low forceps delivery.

Day of Test.-The seventh puerperal morning, counting the day of delivery as the first day.

Drugs.-Oestrogen: Oral stilboestrol $30 \mathrm{mg}$. daily for the first three days after delivery, followed by $20 \mathrm{mg}$. daily up to and including the sixth day of the puerperium. Progestogen : Oral megestrol acetate $30 \mathrm{mg}$. daily for the first three days, followed by $20 \mathrm{mg}$. daily for the fourth, fifth, and sixth days. The women who were breast-feeding had received no oestrogen or progestogen. Night sedation had been discontinued for at least 36 hours before the test in all patients.

\section{Results}

Standard liver function tests were within the normal limits stated above in all the women included in this series.

\section{Modified B.S.P. Test}

For each test the observed concentrations of B.S.P. were plotted on semi-logarithmic paper to give a plasma decay curve. The curve obtained reflects a combination of three events: (1) a rapid disappearance of B.S.P. from the plasma into the liver, (2) return of some of the B.S.P. from the liver back into the plasma, and (3) a slower excretion of dye from the liver into the bile. Each curve approximates to the sum of two exponential curves, and to illustrate this the two components of the progestogen curve in Fig. 1 are shown as straight lines.

The general equation for such a curve shows that plasma concentration $(\mathrm{Cn})$ at any time $(\mathrm{t})$ is as follows:

$$
\mathrm{Cn}(\mathrm{t})=\mathrm{Ae}^{-\mathrm{klt}}+\mathrm{Be}^{-\mathrm{k} 2 \mathrm{t}}
$$

where $\mathrm{A}$ and $\mathrm{B}$ are constants for the point at which each component line crosses the ordinate at zero time; $\mathrm{k}_{1}$ and $\mathrm{k}_{2}$ are the respective constants for the slope of each line. These four constants are used (Richards et al., 1959) to calculate the proportional rates of transfer of B.S.P. from plasma to liver, liver to plasma, and liver to bile ( $a, b$, and $h$ in the insert in Fig. 1). From these the "equivalent plasma volume of the liver" (E.L.V.) of Goetzee et al. (1959) and hepatic plasma clearance (Richards, 1965) can be derived.

Plasma Decay Curves.-Fig. 1 shows the composite curves for each of the three groups of women studied. It will be seen that whereas initially the slopes are similar, after 15 minutes the concentration of B.S.P. in those taking stilboestrol remains at all times higher than the other groups. After 15 minutes the concentrations of B.S.P. in those taking megestrol are always slightly lower than the control group of breast-feeders. These curves illustrate that the disappearance of B.S.P. from

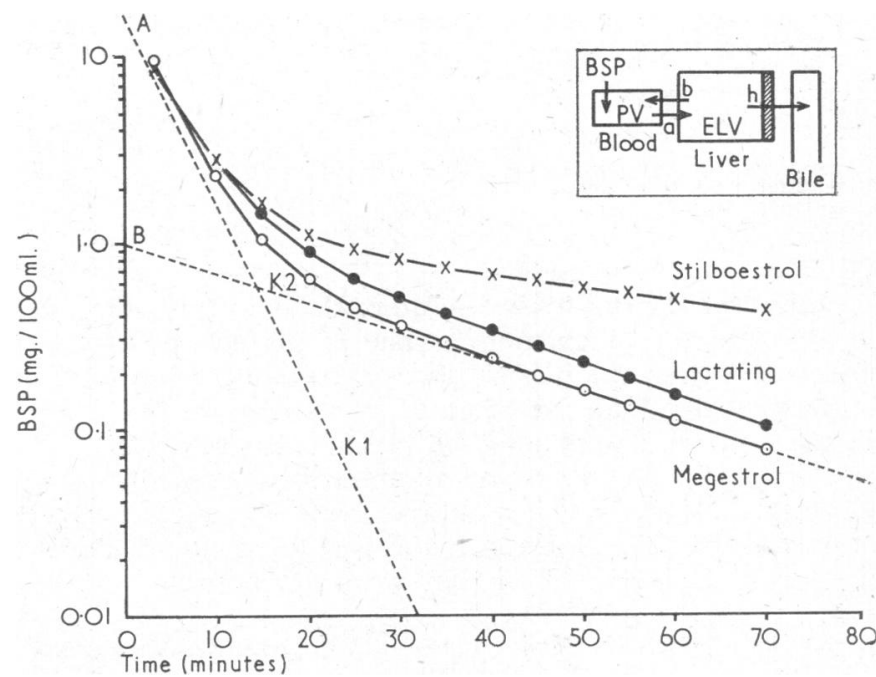

Composite B.S.P. plasma disappearance curves for three groups of puer peral women. The single straight line components of the double exponential megestrol curve are shown separately as dotted lines ( $A k_{1}$ and $\mathrm{Bk}_{2}$ respectively). The model in the inset depicts the pattern of distribution of B.S.P. between the blood, liver, and bile (see text).

the plasma is delayed after stilboestrol compared with either megestrol or the control group.

Transfer Rates of B.S.P.-Table I shows the mean values and standard deviations for the transfer rates of dye in the three groups of women studied. There is no statistical difference for any of the respective rates of intercompartmental transfer of B.S.P. between the lactating women and those who received megestrol. The rate of transfer of B.S.P. to the liver (a) is significantly reduced in women who received stilboestrol compared with those given megestrol $(\mathbf{P}<0.01)$ but not compared with those obtained from lactating women. The rate of return of B.S.P. to the blood (b) is increased significantly after stilboestrol compared with women breast-feeding $(\mathrm{P}<0.01)$ or after megestrol $(P<0.001)$. The rate of transfer of dye from the liver to the bile (h) after stilboestrol is also significantly reduced compared either with the breast-feeders or with women who received megestrol $(P<0.001)$. This indicates that the ability of the liver of a normal puerperal woman to deal with the exogenous dye, B.S.P., is altered considerably after stilboestrol therapy has been given to suppress lactation. This effect was not found when megestrol was given to suppress lactation.

TABLE I.-Rates of Dye Transfer. For Simplicity of Presentation These Are Expressed in mg. Transferred per Minute per $100 \mathrm{mg}$. Con tained in the Compartment From Which the Transfer of B.S.P. is Taking Place (mg./100 mg./min.)

\begin{tabular}{|c|c|c|c|c|c|c|}
\hline & & & \multirow{2}{*}{$\begin{array}{l}\text { No. of } \\
\text { Cases }\end{array}$} & \multicolumn{3}{|c|}{ Direction of Transfer of B.S.P. } \\
\hline & & & & $\begin{array}{l}\text { Blood to Liver } \\
\text { (a) }\end{array}$ & $\begin{array}{l}\text { Liver to Blood } \\
\text { (b) }\end{array}$ & $\begin{array}{l}\text { Liver to Bile } \\
\text { (h) }\end{array}$ \\
\hline $\begin{array}{l}\text { Stilboestrol } \\
\text { Lactating } \\
\text { Megestrol }\end{array}$ & $\begin{array}{l}\cdots \\
\cdots\end{array}$ & $\begin{array}{l}\cdots \\
\cdots\end{array}$ & $\begin{array}{l}24 \\
20 \\
21\end{array}$ & $\begin{array}{l}18 \cdot 68 \pm 3 \cdot 12 \\
20 \cdot 21 \pm 3 \cdot 54 \\
22 \cdot 17 \pm 3 \cdot 71\end{array}$ & $\begin{array}{l}1.52 \pm 0.50 \\
0.99 \pm 0.57 \\
0.93 \pm 0.34\end{array}$ & $\begin{array}{l}1 \cdot 73 \pm 0 \cdot 82 \\
4 \cdot 35 \pm 2 \cdot 54 \\
3 \cdot 98 \pm 1 \cdot 39\end{array}$ \\
\hline
\end{tabular}

Excretory Efficiency of Liver.-The small inset model of intercompartmental dye transfer in Fig. 1 illustrates that once dye has entered the liver the total rate of loss of B.S.P. from the liver in unit time must be the sum of $b$ and $h$. A fraction $(b / b+h)$ will return to the plasma and a fraction $(h / b+h)$ will be eliminated into the bile. The latter proportion, if expressed as a percentage, gives an indication of the efficiency of the process of excretion from the liver cells. Table II shows that about $80 \%$ of the B.S.P. is eliminated into the bile in lactating women and women who received megestrol. However, after stilboestrol only a little over $50 \%$ is directed to the bile. The difference is statistically significant $(P<0.001)$ and confirms that excretory efficiency is reduced after stilboestrol therapy. 
TABLE II.-Proportion of B.S.P. Leaving Liver Cells by a Process of Excretion Into the Bile Expressed as a Percentage (i.e., an Index of the Excretory Efficiency) in the Three Groups of Women Studied

\begin{tabular}{|c|c|c|c|c|c|c|c|}
\hline & & & & & & $\begin{array}{l}\text { No. of } \\
\text { Cases }\end{array}$ & $\begin{array}{l}\text { Excretory Efficiency } \\
(\%) \text { of Liver Cells }\end{array}$ \\
\hline $\begin{array}{l}\text { Stilboestrol } \\
\text { Lactating } \\
\text { Megestrol }\end{array}$ & $\begin{array}{l}\cdots \\
\cdots\end{array}$ & $\begin{array}{l}\cdots \\
\cdots\end{array}$ & $\begin{array}{l}\cdots \\
\cdots\end{array}$ & $\begin{array}{l}\cdots \\
\cdots\end{array}$ & $\begin{array}{l}\cdots \\
\cdots\end{array}$ & $\begin{array}{l}24 \\
20 \\
21\end{array}$ & $\begin{array}{l}52 \cdot 10 \pm 14 \cdot 05 \\
80 \cdot 73 \pm 5 \cdot 50 \\
79 \cdot 09 \pm 9 \cdot 34\end{array}$ \\
\hline
\end{tabular}

Equivalent Liver Volume.-Although B.S.P. is eliminated rapidly from the circulation its rate of disappearance can be determined from the plasma decay curve, so that an estimate of the plasma volume can be made. The "equivalent volume" of the liver with respect to the plasma volume can therefore be calculated. This represents the functional mass of the liver for B.S.P. Table III shows this volume in the three groups of women studied and reveals that it is reduced after stilboestrol $(P<0.02)$ whether based on body weight or not.

TABle III.-Equivalent Plasma Volume of Liver with Respect to Plasma Volume

\begin{tabular}{|c|c|c|c|c|c|c|}
\hline & & & & \multirow{2}{*}{$\begin{array}{l}\text { No. of } \\
\text { Cases }\end{array}$} & \multicolumn{2}{|c|}{ Equivalent Plasma Volume of Liver } \\
\hline & & & & & Litres & Litres/kg. \\
\hline $\begin{array}{l}\text { Stilboestrol } \\
\text { Lactating } \\
\text { Megestrol }\end{array}$ & $\ddot{.}$ & 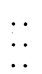 & $\begin{array}{l}\ldots \\
\cdots\end{array}$ & $\begin{array}{l}24 \\
20 \\
21\end{array}$ & $\begin{array}{l}31 \cdot 3 \pm 19 \cdot 3 \\
49 \cdot 2 \pm 26 \cdot 8 \\
45 \cdot 7 \pm 17 \cdot 2\end{array}$ & $\begin{array}{l}0.52 \pm 0.32 \\
0.75 \pm 0.41 \\
0.77 \pm 0.29\end{array}$ \\
\hline
\end{tabular}

Clearance.-With a single injection of B.S.P. the value for the clearance of dye at the time of maximum liver concentration has been shown to be a fraction $(\mathrm{ah} / \mathrm{b}+\mathrm{h})$ of the plasma volume per unit time (Richards, 1965). Table IV shows that the clearance of B.S.P. is significantly reduced $(P<0.001)$ after stilboestrol compared with the results obtained from women who lactated and those who were given megestrol to suppress lactation, whether based on body weight or not.

TABLE IV.-Plasma Clearance of B.S.P. at Time of Maximum Liver Content

\begin{tabular}{|c|c|c|c|c|c|c|}
\hline & & & & \multirow{2}{*}{$\begin{array}{l}\text { No. of } \\
\text { Cases }\end{array}$} & \multicolumn{2}{|c|}{ Clearance } \\
\hline & & & & & $\mathrm{ml} . / \mathrm{min}$. & $\mathrm{ml} . / \mathrm{min} . / \mathrm{kg}$. \\
\hline $\begin{array}{l}\text { Stilboestrol } \\
\text { Lactating . . } \\
\text { Megestrol. }\end{array}$ & $\begin{array}{l}\ldots \\
\cdots\end{array}$ & $\because$ & $\begin{array}{l}\ldots \\
\cdots\end{array}$ & $\begin{array}{l}24 \\
20 \\
21\end{array}$ & $\begin{array}{l}214 \pm 84 \\
294 \pm 54 \\
304 \pm 60\end{array}$ & $\begin{array}{l}3 \cdot 5 \pm 1 \cdot 4 \\
4 \cdot 5 \pm 0 \cdot 8 \\
5 \cdot 1 \pm 1 \cdot 0\end{array}$ \\
\hline
\end{tabular}

\section{Discussion}

Apart from Kleiner et al. (1965) and Stoll et al. (1966) most writers postulate that if there is a disturbance in liver function it is probably due to the oestrogen in any combination therapy. In particular, Mueller and Kappas (1964), using a continuous infusion technique, found that oestradiol in large amounts markedly decreased the liver's ability to transfer the dye to the bile. Preliminary studies of these workers implied that progesterone did not do this. Our results with single injections support this finding, because the rate of transfer of B.S.P. into the bile (h) has been shown to be significantly reduced, as is the excretory efficiency of the liver cells. In addition, we have shown that the equivalent plasma volume of the liver and the hepatic clearance of B.S.P. are significantly reduced after stilboestrol. It must be remembered that in none of our patients did the conventional liver function tests show any abnormality.

Both synthetic oestrogens and progestogens are carried in the blood stream bound to plasma protein (Gray and Bacharach, 1967). The oestrogen is mainly inactivated in the liver but slowly enough to enable a high intrinsic potency to be maintained. Progesterone, too, is inactivated in the liver and also found in the urine conjugated with glucuronic acid. Its turnover in the body, however, is extremely rapid. Little is known of stilboestrol metabolism except that with large doses a glucuronic derivative can be found in the urine.

Megestrol acetate is 6-methyl,17 $\alpha$-acetoxy progesterone. Clinically it has no oestrogenic action (Doran et al., 1964).
Cooke and Vallance (1965) found that the introduction of the 6-methyl group into the progesterone molecule along with a $17 \alpha$-acetoxy group markedly decreased the rate of metabolism of the drug by either rat or rabbit liver preparations in vitro. Both these groups seem to block the action of metabolizing enzymes in the liver, hence increasing and prolonging the progestogenic action. Cooper and Kellie (1968) have shown in man that about $85 \%$ of any dose is excreted unchanged in the urine or faeces. A further 5 to $8 \%$ presents as glucuronide conjugates.

Neither megestrol acetate nor stilboestrol is completely typical of the progestogens and oestrogens usually used in oral contraceptives. Nevertheless, they are clinically representative of the two extremes whose effect on the liver we wished to study, in that megestrol is solely progestogenic and stilboestrol is solely oestrogenic. Thus the results reported here may have clinical significance. At present a wide variety of metabolic side-effects have been reported in patients taking progestogens or oestrogens which could be due to their effect on the liver.

Daniel et al. (1968) showed increased levels of factor IX in puerperal patients treated with stilboestrol. According to Wessler et al. (1967), working with rabbits, an intact hepatic circulation is necessary for the clearance of activated factor IX from the serum. Wynn and Doar (1966), writing about the effects of oral contraceptives on carbohydrate metabolism, pointed out the strikingly high incidence of raised blood pyruvate in these patients. The liver is an important source of pyruvate utilization. Pyörälä et al. (1967), using a sequential type tablet with ethinyloestradiol and megestrol acetate, found that the oestrogen caused a fall in carbohydrate tolerance as measured by an intravenous glucose tolerance test. Later in the cycle, when megestrol acetate was combined with the oestrogen, the glucose tolerance returned to normal. Wynn et al. (1966) also found raised levels of serum lipids in patients on oral contraceptives. This resembles the hyperlipidaemia of pregnancy thought by Svanborg and Vikrot (1965) to be due to hepatic dysfunction. Burton et al. (1967) showed increased urinary coproporphyrin excretion in these patients, and Burton (1967) also showed changes in total iron-binding capacity and serum iron. Robertson (1967) reported abnormal serum proteins and cholinesterase levels.

The present study implies that in so far as these alterations represent liver dysfunction they are due to the oestrogen component in any combined preparation. The study also suggests that low-dose therapy with one of the 17-hydroxy progesterone derivatives should avoid any hepatotoxicity. MartinezManautou et al. (1967) and Zañartu et al. (1968) showed these to be highly effective as contraceptives.

We are grateful to Professor A. C. Turnbull, Mr. M. D. Arwyn Evans, and Mr. J. G. Lawson for permission to study patients under their care. Also to British Drug Houses for supplies of megestrol acetate. One of us (J. C.) was in receipt of a Jane Hodge Foundation Scholarship during this study.

\section{REFERENCES}

Adlercreutz, H., and Ikonen, E. (1964). Brit. med. f., 2, 1133. Barber-Riley, G., Goetzee, A. E., Richards, T. G., and Thomson, J. Y. (1961). Clin. Sci., 20, 149.

Brown, J. B., and Blair, H. A. F. (1960). Proc. roy. Soc. Med., 53, 433. Burton, J. L. (1967). Lancet, 1, 978.

Burton, J. L., Loudon, N. B., and Wilson, A. T. (1967). Lancet, 2, 1326

Cooke, B. A., and Vallance, D. K. (1965). Biochem. F., 97, 672.

Cooper, J. M., and Kellie, A. E. (1968). Steroids, 11, 133.

Daniel, D. G., Bloom, A. L., Giddings, J. C., Campbell, H., and Turnbull, A. C. (1968). Brit. med. F., 1, 801 .' Doran, T. A., Harkins, J. L., Gornall, A. G., and Thompson, D. W.

Eisalo, A., Järvinen, P. A., and Luukkäinen, T. (1964). Brit. med. f., 2, 426.

Eisalo, A., Heino, A., and Räsänen, V. (1968). Acta obstet. gynec. scand., $47,58$.

Goetzee, A. E., Richards, T. G., and Riley, G. B. (1959). F. Physiol., $149,40 \mathrm{P}$.

Gray, C. H., and Bacharach, A. L. (editors) (1967). Hormones in Blood, 2nd ed., vol. 2, p. 125. New York and London.

Kleiner, G. J., Kresch, L., and Arias, I. M. (1965). New Engl. f. Med., 273,420 . 


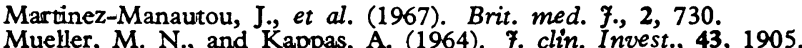
Ockner, R. K., and Davidson, C. S. (1967). New Engl. f. Med., 276 331. R. K., and Davidson, C. S. (1967). New Engl. F. Med., 276,

Paulsen, C. A., Leach, R. B., Lanman, J., Goldston, N., Maddock, W. O., and Heller, C. G. (1962). F. clin. Endocr., 22, 1033.

Pyörälä, K., Pyörälä, T., and Lampinen, V. (1967). Lancet, 2, 776.

Richards, T. G. (1965). In The Biliary System, edited by W. Taylor, p. 567. Oxford.

Richards, T. G., Tindall, V. R., and Young, A. (1959). Clin. Sci., 18,

Robertson, G. S. (1967). Lancet, 1, 232.
Stoll, B. A., Andrews, J. T., and Motteram, R. (1966). Brit. med. F., 1, 960.

Svanborg, A., and Vikrot, O. (1965). Acta med. scand., 178, 615.

Tindall, V. R., and Beazley, J. M. (1965). F. Obstet. Gynaec. Brit. Cwlth, 72, 717.

Wessler, S., Yin, E. T., Gaston, L. W., and Nicol, I. (1967). Thrombos. Diathes. haemorrh. (Stuttg.) 18, 12.

Wynn, V., and Doar, J. W. H. (1966). Lancet, 2, 715.

Wynn, V., Doar, J. W. H., and Mills, G. L. (1966). Lancet, 2, 720.

Zañantu, J. Rodriguez-Moore, G., Pupkin, M., Salas, O., and Guerrero, R. (1968). Brit. med. F., 2, 263.

\title{
Protein Content of Liquor Amnii in Prediction of Severity of Haemolytic Disease of Newborn
}

\author{
W. WALKER,* M.D. ; M. J. LANDON,† B.SC. ; A. OXLEY,‡ F.I.M.L.T.
}

Brit. med. F., 1969, 1, 605-607

\begin{abstract}
Summary : Two series of cases of $R h$ isoimmunization were subjected to liquor examination for bilirubin and protein level. Series 1 comprised 298 cases for the years 1962 and 1963 . Series 2 comprised 179 consecutive cases for 1967 in which preliminary selection for liquor examination had been made on the basis of previous history and maternal antibody titre.

Bilirubin was measured as the liquor bilirubin ratio, and protein levels were estimated in series 1 by the Folin and Ciocalteau technique and in series 2 by a modified biuret method.
\end{abstract}

Correlations with severity of haemolytic disease in the foetus was made, taking into account the stage of gestation of liquor examination. Both bilirubin and protein levels correlate with severity, but bilirubin is superior to protein. Interrelation of these measurements as bilirubin/protein ratio was inferior to bilirubin level as a method of forecasting severity.

\section{Introduction}

The spectroscopic examination of liquor amnii during pregnancy for the presence of bilirubin is established in the management of $\mathrm{Rh}$ isoimmunization, though different methods of measuring the concentration of this pigment have been advocated (Scott, 1959 ; Liley, 1963 ; Walker et al., 1964 ; Knox et al., 1965). Wild (1961) suggested that liquor bilirubin levels may be influenced by the protein level as has been demonstrated for cerebrospinal fluid (Stempfel and Zetterström, 1955). Both bilirubin and protein levels normally fall as pregnancy advances, so allowances must be made for the stage of gestation when interpreting these values. Cherry et al. (1965) and Morris et al. (1967) recommended that both bilirubin and protein levels are taken into account by calculating the bilirubin/ protein ratio. If, as they believe, the protein value gives an indication of liquor volume, this method should eliminate errors due to fluctuation of the liquor volume. We (Walker et al., 1964) had previously estimated protein and bilirubin levels and in view of this new suggestion calculated the bilirubin/protein ratio for that material. Our findings were at variance with those of Cherry et al. and Morris et al., but we had used a different method of estimating protein. We have therefore studied a further series of cases in which protein was estimated by the biuret method as they recommend.

This confirms the findings of the earlier study and the results of both series are presented.

\footnotetext{
* Reader in Paediatric Haematology.

+ Research Officer.

I Senior Technician.

Department of Child Health, the University of Newcastle upon Tyne.
}

\section{Materials and Methods}

All liquor samples were obtained by amniocentesis and immediately placed in brown universal containers. Any contaminated with blood were discarded. Samples were Seitz filtered by means of a Hemming filter and the absorption spectrum was traced over the range $360-630 \mathrm{~m} \mu$ with a $0 \cdot 5-\mathrm{cm}$. light path. The level of bilirubin was expressed as the ratio transmission $520 \mathrm{~m} \mu /$ transmission $490 \mathrm{~m} \mu$ (Knox et al., 1965).

The sample was then frozen until required for protein estimation.

Two series of patients with $\mathrm{Rh}$ isoimmunization were studied: (1) 298 samples from 1962 and 1963 where the protein was estimated by the Folin and Ciocalteau method (Papadopoulos et al., 1959), and (2) 179. consecutive samples from 1967 where protein was estimated by the biuret method as recommended by Morris et al. (1967).

The levels of bilirubin and protein and the bilirubin/protein ratio were related to severity of haemolytic disease in the infant, initially for the six categories: (1) Rh-negative unaffected infant ; (2) mild disease, Coombs positive, no treatment required ; (3) moderate disease, transfusion required, cord $\mathrm{Hb}$ $>11.5$ g. $/ 100 \mathrm{ml}$; (4) severe disease, transfusion or repeated exchange transfusion required, cord $\mathrm{Hb}$ usually $<11.5 \mathrm{~g} . /$ $100 \mathrm{ml}$; (5) very severe disease, overt severe clinical disease at birth, cord $\mathrm{Hb}$ usually $<7.4 \mathrm{~g}$. $/ 100 \mathrm{ml}$; and (6) stillbirth due to haemolytic disease.

The essential purpose of liquor examination, however, is to select patients for premature induction and/or intrauterine transfusion. We have therefore found it satisfactory to forecast the results in two major classes-that is, those resulting in stillbirth or very severe disease in whom special treatment is justified compared with those having less severe disease or negative infants.

Similarly, in the tables only the protein or bilirubin value giving best discrimination has been used, so that the original $6 \times N$ tables are simplified to $2 \times 2$ tables and for these $\chi^{2}$ and $Q$ have been calculated.

\section{Results}

\section{Reliability of Protein Estimation}

Twenty specimens of liquor were divided into two aliquots each. One was assayed fresh-that is, after less than five days' storage at $4^{\circ} \mathrm{C}$. - and the other after storage at $-20^{\circ} \mathrm{C}$. for a period of three months (Table I). There was no significant difference between the two sets of results. 